\title{
THE OPTIMISATION OF UNDERWATER EXPLORATION STRATEGIES WHICH ARE TO BE IMPLEMENTED FOR PROCESS DEVELOPMENT PURPOSES
}

\section{Adam Olejnik}

Faculty of Mechanical and Electrical Faculty, Polish Naval Academy Gdynia, Poland

\section{ABSTRACT}

This material is a continuation of the article published in the PHR no. 3(52)2015 concerning the methodology of selecting underwater exploration strategies for process development purposes. The article proposes to use one of the methods of decision optimization for the selection of the appropriate course of action in such cases.

Keywords: mechanical engineering, maritime engineering, underwater works technology.

ARTICLE INFO

PolHypRes 2019 Vol. 66 Issue 1 pp. 35 - 46

ISSN: $1734-7009$ eISSN: 2084-0535

DOI: $10.2478 / \mathrm{phr}-2019-0003$

Pages: 12, figures: 1 , tables: 8

page www of the periodical: www.phr.net.pl

Publisher

Polish Hyperbaric Medicine and Technology Society

\section{Review article}

Submission date: $07.11 .2018 \mathrm{r}$ Acceptance for print: 28.12.2018 r 


\section{INTRODUCTION}

This is a second article devoted to issues related to the planning and execution of underwater searches for process orientated purposes. The first one was published in 2015 in Polish Hyperbaric Research No. 3(52) [1] and discussed the impact of the location and conditions of the exploration on the choice of strategy. Moreover, the notion of exploration strategy was defined as actions aimed at the development and execution of a search plan realised with the use of a specific search methodology, understood in technical terms. This article is a continuation of this subject and presents a proposition of a method for optimising the strategy of such searches.

The choice of an optimal strategy for underwater exploration is in fact a classic decision making process in which the following phases are distinguished [2]:

- identification of a situation in which decisions are taken,

- formulation of the decision-making problem,

- building a decision-making model

- determination of allowable decisions,

- determination of the optimal decision,

- taking the final decision.

Counter intuitively, the choice of an optimal search strategy is a complex issue, where many factors occur and it is difficult to determine direct dependencies between the components of the criterion function and the factors, hence it is justified to make decisions in the mode of an optimisation task. In general, solving this task should lead to the achievement of the desired goal, with the involvement of minimum effort and resources, which in turn translates into a reduction in exploration costs. In the discussed case, there may be many factors directly influencing the selection of the appropriate search strategy, for example: the size of the body of water, the nature of the bottom, the size of the object being searched for, density of vegetation, etc.

The presence of such factors raises the question of how to assess their influence, here understood as criteria for the selection of a strategy, on the final decision. The answer to such a question is provided by the department for multi-criteria optimisation. It is quite a complex issue, but it is possible to find a single, concrete solution [3].

Comparison of the selected decision options against different criteria requires the collection of relevant information concerning the assessment of these options against all selected criteria. Due to the different nature of these criteria, which are expressed through different scores in terms of size and titre, it is necessary to organise them in a systematic way. As a rule, this involves the appropriate standardisation of assessments, i.e. their normalisation. There are several formulas for standardising the assessment of criteria, according to some researchers none of them is entirely positive, but the method characterised by the highest number of positives is the zero unitarisation method [4].

This method evaluates a finite number of decision options and is characterised by the adoption of a fixed benchmark, which is constituted by the range of a standardised variable. It can be said that it is a method that allows the choosing of the variant that is the least distant from the hypothetical target point, understood here as the optimal variant for the given decision-making process. Its application in the decision making process concerning the selection of an exploration strategy will be presented on an example.

\section{EXAMPLE}

Typically, a specialist in underwater technology in criminal preparatory proceedings appears as a case expert, once the State authorities have established and selected, on the basis of investigative measures, the body of water or part of a body of water to be searched in order to find evidence of a criminal offence.

His or her task, together with a team of coworkers, is to select the appropriate search strategy and find the evidence in question, which will confirm or reject the investigative hypothesis. Let us assume that the analysed case involved a shallow inland body of water having no connection with other bodies of water and rivers.

The body of water is characterised by a significant presence of vegetation in the water and poor visibility, and additionally a silty bottom. The task entails locating and extracting a military object in the body of water that can confirm the involvement of a crown witness in a murder, which is important for establishing his credibility. However, on the basis of the testimonies of witnesses, it was not possible to narrow down the search area and therefore it is required to explore the entire body of water. Therefore, a situation arises which can be described as a decision dilemma: how to effectively search a selected body of water in order to find evidence or rule out the existence of such evidence in that body of water.

At least eight methods used in the underwater technology can be used to carry out such searches and the number of options may increase if a specialist decides to utilise combined options. If, however, he/she decided to test each method in turn, the state authorities would be exposed to significant costs related to their implementation, as there is no certainty that the solution best suited to the situation would be randomly selected as first. It therefore seems appropriate to first resolve the decision-making dilemma as an optimalisation task.

The characteristics of the body of water selected for the search allows us to identify nine criteria by which we will evaluate particular decision-making variants, in this case understood as selecting the optimal search method. These are:

- inland body of water,

- stagnant water,

- small depth,

- muddy bottom,

- large area,

- poor visibility,

- small object,

- ferromagnetic object,

- vegetation in water.

The first step is to analyse the potential exploration methods in terms of the characteristics and conditions of the body of water as shown in Table 1 (example table based on [5]). 


\begin{tabular}{|c|c|c|c|}
\hline Method & Advantages & Disadvantages & Body of water \\
\hline \multicolumn{4}{|l|}{ Hyperbaric } \\
\hline \multirow{3}{*}{ Pendular } & $\begin{array}{l}\text { Relatively moderate labour } \\
\text { intensity regarding marking } \\
\text { of the search sector and } \\
\text { search strip. }\end{array}$ & $\begin{array}{l}\text { A very labour-intense method for } \\
\text { divers. }\end{array}$ & \multirow{3}{*}{$\begin{array}{l}\text { Inland body of water or } \\
\text { limited sea water of } \\
\text { medium depth with hard } \\
\text { bottom and good visibility, } \\
\text { vegetation may occur in the } \\
\text { body of water. }\end{array}$} \\
\hline & \multirow[t]{2}{*}{$\begin{array}{l}\text { Overlapping of search strips } \\
\text { increasing the probability of } \\
\text { detecting an object. }\end{array}$} & $\begin{array}{l}\text { Does not provide a visible } \\
\text { boundary of the side search strip, } \\
\text { which makes it possible to } \\
\text { overlook the object. }\end{array}$ & \\
\hline & & $\begin{array}{l}\text { Not suitable for use with muddy } \\
\text { bottoms. }\end{array}$ & \\
\hline \multirow{3}{*}{ Field } & $\begin{array}{l}\text { Limitation of diver activity } \\
\text { only to moving across the } \\
\text { bottom in a designated strip } \\
\text { and conducting observa- } \\
\text { tions. }\end{array}$ & $\begin{array}{l}\text { Highly labour-intensive marking } \\
\text { of the exploration sector. }\end{array}$ & \multirow{3}{*}{$\begin{array}{l}\text { Inland body of water or } \\
\text { restricted sea basin of } \\
\text { medium depth with muddy } \\
\text { bottom of moderate } \\
\text { visibility. Vegetation in } \\
\text { water may occur and hinder } \\
\text { activities. }\end{array}$} \\
\hline & $\begin{array}{l}\text { Can be used in a body of } \\
\text { water with a muddy bottom }\end{array}$ & \multirow[t]{2}{*}{$\begin{array}{l}\text { Diver searches the strip once, } \\
\text { regardless of its length. }\end{array}$} & \\
\hline & $\begin{array}{l}\text { Visible boundaries of the } \\
\text { search strip facilitating } \\
\text { divers' work. }\end{array}$ & & \\
\hline \multirow{4}{*}{ Circular } & Simplicity of execution. & $\begin{array}{l}\text { Very low method effectiveness in } \\
\text { searching large areas of the } \\
\text { seabed. }\end{array}$ & \multirow{4}{*}{$\begin{array}{l}\text { A small inland body of } \\
\text { water or very limited sea } \\
\text { water of medium depth and } \\
\text { low visibility. Vegetation } \\
\text { may be present in the water } \\
\text { and hamper the } \\
\text { implementation of the } \\
\text { works. }\end{array}$} \\
\hline & $\begin{array}{l}\text { High method efficiency } \\
\text { when searching for objects }\end{array}$ & $\begin{array}{l}\text { Possibility to use the method } \\
\text { when the search regions are very }\end{array}$ & \\
\hline & $\begin{array}{l}\text { of considerable sizes that } \\
\text { protrude from the bottom to } \\
\text { a greater height than the } \\
\text { distance rope. }\end{array}$ & precisely defined. & \\
\hline & $\begin{array}{l}\text { Possibility to conduct } \\
\text { searches with little visibility. }\end{array}$ & & \\
\hline \multirow{5}{*}{ Tack } & $\begin{array}{l}\text { Quick exploration of a large } \\
\text { body of water. }\end{array}$ & Search limited to large objects. & \multirow{5}{*}{$\begin{array}{l}\text { Large sea or restricted } \\
\text { inland body of water of } \\
\text { medium depth with very } \\
\text { good visibility and no } \\
\text { vegetation in the water. No } \\
\text { infrastructure at the } \\
\text { bottom. }\end{array}$} \\
\hline & \multirow[t]{4}{*}{$\begin{array}{l}\text { Possibility to carry out } \\
\text { exploration at great depths. }\end{array}$} & $\begin{array}{l}\text { Limitation of use to high visibility } \\
\text { areas. }\end{array}$ & \\
\hline & & Hazardous method for divers. & \\
\hline & & $\begin{array}{l}\text { Work in an area with no bottom } \\
\text { structures. }\end{array}$ & \\
\hline & & $\begin{array}{l}\text { Possibility of omissions of } \\
\text { fragments of the bottom that } \\
\text { require searching. }\end{array}$ & \\
\hline \multirow{5}{*}{ Tow } & $\begin{array}{l}\text { Quick search of a large body } \\
\text { of water. }\end{array}$ & $\begin{array}{l}\text { Search limited to large and well } \\
\text { visible objects }\end{array}$ & \multirow{5}{*}{$\begin{array}{l}\text { Large sea or restricted } \\
\text { inland body of water of } \\
\text { medium depth with very } \\
\text { good visibility and no } \\
\text { vegetation in the water. No } \\
\text { infrastructure at the } \\
\text { bottom. }\end{array}$} \\
\hline & \multirow[t]{4}{*}{$\begin{array}{l}\text { Possibility to carry out } \\
\text { exploration at great depths. }\end{array}$} & $\begin{array}{l}\text { Limitation of use to high visibility } \\
\text { areas. }\end{array}$ & \\
\hline & & $\begin{array}{l}\text { Method requiring a high level of } \\
\text { diving qualifications in swimming } \\
\text { along a given course. }\end{array}$ & \\
\hline & & $\begin{array}{l}\text { Work in an area with no bottom } \\
\text { structures. }\end{array}$ & \\
\hline & & $\begin{array}{l}\text { Possibility of omissions of } \\
\text { fragments of the bottom that } \\
\text { require searching. }\end{array}$ & \\
\hline
\end{tabular}


Characterisation of search methods vs. the body of water and its conditions.

\begin{tabular}{|c|c|c|c|}
\hline Method & Advantages & Disadvantages & Body of water \\
\hline & & $\begin{array}{l}\text { Possibility of omissions of } \\
\text { fragments of the bottom that } \\
\text { require searching. }\end{array}$ & \\
\hline \multicolumn{4}{|l|}{ Unmanned } \\
\hline \multirow{5}{*}{ Sonar survey } & Very high work efficiency. & Expensive equipment. & \multirow{5}{*}{$\begin{array}{l}\text { A large sea or inland body } \\
\text { of water of any depth with } \\
\text { little visibility in the water } \\
\text { and usually a hard bottom. } \\
\text { The presence of vegetation } \\
\text { hinders activities. }\end{array}$} \\
\hline & $\begin{array}{l}\text { No need to prepare the body } \\
\text { of water. }\end{array}$ & $\begin{array}{l}\text { The need for underwater } \\
\text { navigation equipment. }\end{array}$ & \\
\hline & $\begin{array}{l}\text { Very good representation of } \\
\text { the results of the research, } \\
\text { but often without the } \\
\text { possibility of identifying an }\end{array}$ & $\begin{array}{l}\text { The necessity to perform post- } \\
\text { processing of measurement data } \\
\text { for the purpose of their } \\
\text { presentation and georeferencing. }\end{array}$ & \\
\hline & $\begin{array}{l}\text { object with a } 100 \% \\
\text { certainty. }\end{array}$ & $\begin{array}{l}\text { Data interpretation requires staff } \\
\text { with extensive experience and } \\
\text { qualifications. }\end{array}$ & \\
\hline & & $\begin{array}{l}\text { Identification of a localised object } \\
\text { often requires the use of } \\
\text { a television method. }\end{array}$ & \\
\hline \multirow{5}{*}{ Magnetic } & Very high work efficiency. & Expensive equipment. & \multirow{5}{*}{$\begin{array}{l}\text { A large sea or inland body } \\
\text { of water of any depth with } \\
\text { little visibility in the water } \\
\text { and usually a hard bottom. } \\
\text { The presence of vegetation } \\
\text { hinders activities. }\end{array}$} \\
\hline & $\begin{array}{l}\text { No need to prepare the body } \\
\text { of water. }\end{array}$ & $\begin{array}{l}\text { The need for underwater } \\
\text { navigation equipment. }\end{array}$ & \\
\hline & $\begin{array}{l}\text { Very good representation of } \\
\text { the results of the research, } \\
\text { but often without the } \\
\text { possibility of identifying an }\end{array}$ & $\begin{array}{l}\text { The necessity to perform post- } \\
\text { processing of measurement data } \\
\text { for the purpose of their } \\
\text { presentation and georeferencing. }\end{array}$ & \\
\hline & 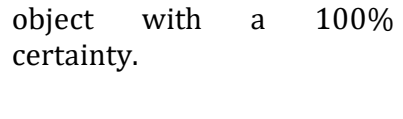 & $\begin{array}{l}\text { Data interpretation requires staff } \\
\text { with extensive experience and } \\
\text { qualifications. }\end{array}$ & \\
\hline & & $\begin{array}{l}\text { Identification of a localised object } \\
\text { often requires the use of } \\
\text { a television method. }\end{array}$ & \\
\hline \multirow{4}{*}{ Television } & $\begin{array}{l}\text { No need to prepare the body } \\
\text { of water }\end{array}$ & Expensive equipment. & \multirow{4}{*}{$\begin{array}{l}\text { A limited inland body of } \\
\text { water or considerably } \\
\text { limited sea water with very } \\
\text { good visibility, any depth, } \\
\text { hard bottom. Vegetation in } \\
\text { water significantly hinders } \\
\text { activities. }\end{array}$} \\
\hline & $\begin{array}{l}\text { Very good result imaging } \\
\text { allowing object identifica- } \\
\text { tion with a } 100 \% \text { certainty. }\end{array}$ & $\begin{array}{l}\text { The need for underwater } \\
\text { navigation equipment. }\end{array}$ & \\
\hline & $\begin{array}{l}\text { High standard of safety in } \\
\text { the execution of works. }\end{array}$ & $\begin{array}{l}\text { Necessity to } \\
\text { hydrographic reconnaissance. }\end{array}$ & \\
\hline & & $\begin{array}{l}\text { The need to post-process video } \\
\text { data. }\end{array}$ & \\
\hline
\end{tabular}

The data from the table above will allow us to define the values of the assessments of individual criteria for the analysed case. For this purpose, we adopt a ninegrade assessment scale (Table 2).

\begin{tabular}{|c|c|c|c|c|c|c|c|c|}
\hline \multicolumn{9}{|c|}{$x_{i j}$} \\
\hline 1 & 2 & 3 & 4 & 5 & 6 & 7 & 8 & 9 \\
\hline $\begin{array}{l}\text { Catastrophic } \\
\text { situation }\end{array}$ & $\begin{array}{l}\text { High risk } \\
\text { situation }\end{array}$ & $\begin{array}{l}\text { Medium } \\
\text { risk } \\
\text { situation }\end{array}$ & $\begin{array}{l}\text { Low risk } \\
\text { situation }\end{array}$ & $\begin{array}{l}\text { Permissible } \\
\text { situation }\end{array}$ & $\begin{array}{l}\text { Satisfactory } \\
\text { situation }\end{array}$ & $\begin{array}{l}\text { Good } \\
\text { situation }\end{array}$ & $\begin{array}{l}\text { Very good } \\
\text { situation }\end{array}$ & $\begin{array}{l}\text { Ideal } \\
\text { situation }\end{array}$ \\
\hline
\end{tabular}


Then, using the method of competent judges, in the group of experts, an assessment of particular criteria should be made in the analysed case of a decision dilemma. The results are presented in the following table.

Tab. 3

Evaluation of particular criteria

\begin{tabular}{|c|c|c|c|c|c|c|c|c|c|}
\hline & Criterion 1 & $\begin{array}{l}\text { Criterion } \\
2\end{array}$ & $\begin{array}{l}\text { Criterion } \\
3\end{array}$ & $\begin{array}{l}\text { Criterion } \\
4\end{array}$ & $\begin{array}{l}\text { Criterion } \\
5\end{array}$ & Criterion 6 & $\begin{array}{l}\text { Criterion } \\
7\end{array}$ & $\begin{array}{l}\text { Criterion } \\
8\end{array}$ & $\begin{array}{l}\text { Criterion } \\
9\end{array}$ \\
\hline Method & $\begin{array}{l}\text { Inland } \\
\text { body of } \\
\text { water }\end{array}$ & $\begin{array}{l}\text { Stagnant } \\
\text { water }\end{array}$ & $\begin{array}{l}\text { Small } \\
\text { depth }\end{array}$ & $\begin{array}{l}\text { Muddy } \\
\text { bottom }\end{array}$ & Large area & $\begin{array}{l}\text { Poor } \\
\text { visibility }\end{array}$ & $\begin{array}{l}\text { Small } \\
\text { object }\end{array}$ & $\begin{array}{l}\text { Ferromagnetic } \\
\text { object }\end{array}$ & $\begin{array}{l}\text { Vegetation } \\
\text { in water }\end{array}$ \\
\hline Pendulum & 7 & 7 & 9 & 2 & 6 & 2 & 3 & 5 & 1 \\
\hline Field & 9 & 9 & 8 & 6 & 4 & 7 & 5 & 5 & 7 \\
\hline Circular & 8 & 8 & 7 & 8 & 1 & 8 & 3 & 7 & 9 \\
\hline Tack & 9 & 9 & 7 & 2 & 8 & 2 & 2 & 4 & 1 \\
\hline Tow & 9 & 9 & 7 & 2 & 8 & 2 & 2 & 4 & 1 \\
\hline $\begin{array}{l}\text { Sonar } \\
\text { survey }\end{array}$ & 8 & 8 & 3 & 2 & 9 & 9 & 7 & 2 & 2 \\
\hline Magnetic & 8 & 8 & 3 & 2 & 9 & 9 & 7 & 9 & 2 \\
\hline Television & 9 & 9 & 7 & 2 & 1 & 1 & 3 & 5 & 1 \\
\hline
\end{tabular}

The next step is to define the validity of each criterion, which is done using a weighted score. In this case, the assessment of validity can be based on a fivestep scale, as shown in Table 4.

Criterion importance scale

\begin{tabular}{l|l|l|l|l}
\hline \multicolumn{5}{c}{$\boldsymbol{w}_{\boldsymbol{j}}$} \\
\hline $\mathbf{1}$ & $\mathbf{2}$ & $\mathbf{3}$ & $\mathbf{4}$ & $\mathbf{5}$ \\
\hline $\begin{array}{l}\text { Insignificant } \\
\text { criterion }\end{array}$ & $\begin{array}{l}\text { Significant } \\
\text { criterion }\end{array}$ & $\begin{array}{l}\text { Important } \\
\text { criterion }\end{array}$ & $\begin{array}{l}\text { Very } \\
\text { important } \\
\text { criterion }\end{array}$ & $\begin{array}{l}\text { The most } \\
\text { important } \\
\text { criterion }\end{array}$ \\
\hline
\end{tabular}

The assessment of validity of the criteria should also be made using the method of competent judges. The results for the analysed example are summarized in the table below.

Weight of particular criteria.

\begin{tabular}{|c|c|c|c|c|c|c|c|c|c|}
\hline & Criterion 1 & $\begin{array}{l}\text { Criterion } \\
2\end{array}$ & $\begin{array}{l}\text { Criterion } \\
3\end{array}$ & $\begin{array}{l}\text { Criterion } \\
4\end{array}$ & Criterion 5 & Criterion 6 & Criterion 7 & Criterion 8 & Criterion 9 \\
\hline & $\begin{array}{l}\text { inland } \\
\text { body of } \\
\text { water }\end{array}$ & $\begin{array}{l}\text { stagnant } \\
\text { water }\end{array}$ & $\begin{array}{l}\text { small } \\
\text { depth }\end{array}$ & $\begin{array}{l}\text { slimy } \\
\text { bottom }\end{array}$ & $\begin{array}{l}\text { large } \\
\text { surface }\end{array}$ & $\begin{array}{l}\text { poor } \\
\text { visibility }\end{array}$ & small object & $\begin{array}{l}\text { ferromagnetic } \\
\text { object }\end{array}$ & $\begin{array}{l}\text { vegetation } \\
\text { in water }\end{array}$ \\
\hline WEIGHT & 1 & 1 & 1 & 4 & 4 & 5 & 5 & 5 & 4 \\
\hline
\end{tabular}


In case when the weights of particular criteria are differentiated, as above, it is necessary to introduce a standardised weight for each of the criteria:

$$
\varpi_{j}=\frac{w_{j}}{\sum w_{j}}
$$

$\varpi_{j} \quad$ standardised criterion weight,

$w_{j} \quad$ criterion weight
However, the standardised scales introduced must meet the following condition:

$$
\sum \varpi_{j}=1
$$

Meeting the above condition guarantees that the assumption that all criteria are taken into account in the analysis is fulfilled.

\begin{tabular}{|c|c|c|c|c|c|c|c|c|c|c|}
\hline & \multicolumn{9}{|c|}{ Criterion no. } & \multirow{2}{*}{$\begin{array}{l}\text { Total } \\
\text { weight }\end{array}$} \\
\hline & 1 & 2 & 3 & 4 & 5 & 6 & 7 & 8 & 9 & \\
\hline $\begin{array}{c}\text { WEIGHT } \\
w_{j}\end{array}$ & 1 & 1 & 1 & 4 & 4 & 5 & 5 & 5 & 4 & 30 \\
\hline $\begin{array}{l}\text { Standardised } \\
\text { weight } \varpi_{j}\end{array}$ & 0.033333 & 0.033333 & 0.033333 & 0.133333 & 0.133333 & 0.166667 & 0.1666667 & 0.1666667 & 0.133333 & 1 \\
\hline
\end{tabular}

Weight standardisation for particular criteria

The next step is to calculate the range of scores for each criterion:

$$
R\left(X_{j}\right)=\max \left(x_{i j}\right)-\min \left(x_{i j}\right) \text { for all } i \text { elements }
$$

For example, for criterion 1 (inland body of water) the assessment varies with respect to each method and ranges from a minimum value 7 to a maximum value 9, in which case the result calculated from equation (3) is 2. The results of all calculations are presented in the table below:

\begin{tabular}{|c|c|c|c|c|c|c|c|c|c|}
\hline & Criterion 1 & $\begin{array}{l}\text { Criterion } \\
2\end{array}$ & $\begin{array}{l}\text { Criterion } \\
3\end{array}$ & $\begin{array}{l}\text { Criterion } \\
4\end{array}$ & Criterion 5 & Criterion 6 & Criterion 7 & Criterion 8 & Criterion 9 \\
\hline Method & $\begin{array}{l}\text { inland } \\
\text { body of } \\
\text { water }\end{array}$ & $\begin{array}{l}\text { stagnant } \\
\text { water }\end{array}$ & $\begin{array}{l}\text { small } \\
\text { depth }\end{array}$ & $\begin{array}{l}\text { muddy } \\
\text { bottom }\end{array}$ & $\begin{array}{l}\text { large } \\
\text { surface }\end{array}$ & $\begin{array}{l}\text { poor } \\
\text { visibility }\end{array}$ & small object & $\begin{array}{l}\text { ferromagnetic } \\
\text { object }\end{array}$ & $\begin{array}{l}\text { vegetation } \\
\text { in water }\end{array}$ \\
\hline Pendulum & 7 & 7 & 9 & 2 & 6 & 2 & 3 & 5 & 1 \\
\hline Field & 9 & 9 & 8 & 6 & 4 & 7 & 5 & 5 & 7 \\
\hline Circular & 8 & 8 & 7 & 8 & 1 & 8 & 3 & 7 & 9 \\
\hline Tack & 9 & 9 & 7 & 2 & 8 & 2 & 2 & 4 & 1 \\
\hline Tow & 9 & 9 & 7 & 2 & 8 & 2 & 2 & 4 & 1 \\
\hline $\begin{array}{l}\text { Sonar } \\
\text { survey }\end{array}$ & 8 & 8 & 3 & 2 & 9 & 9 & 7 & 2 & 2 \\
\hline Magnetic & 8 & 8 & 3 & 2 & 9 & 9 & 7 & 9 & 2 \\
\hline Television & 9 & 9 & 7 & 2 & 1 & 1 & 3 & 5 & 1 \\
\hline $\min$ & 7 & 7 & 3 & 2 & 1 & 1 & 2 & 2 & 1 \\
\hline $\max$ & 9 & 9 & 9 & 8 & 9 & 9 & 7 & 9 & 9 \\
\hline $\mathrm{R}$ & 2 & 2 & 6 & 6 & 8 & 8 & 5 & 7 & 8 \\
\hline
\end{tabular}

Calculation results for equation (3) for particular methods and criteria 
After making these calculations, it is possible to proceed to building an aggregated function of the objective, which will be used to select the decision variant. This function is built on the basis of the following relation:

$$
Q_{j}=\sum_{j=1}^{s}\left(Z_{i j} \cdot \varpi_{j}\right)
$$

Where $Z_{i j}$ is the normalised value of scores for each criterion $x_{i j}$. The process of converting the values of comparable scores for all analysed criteria, i.e. their standardisation, is carried out in various ways depending on whether the assessment is a stimulant, de-stimulant or a neutral variable [6]. For a stimulant, the variable is normalised by means of the following equation:

$$
Z_{i j}=\frac{x_{i j}-\min \left(x_{i j}\right)}{R\left(X_{j}\right)}
$$
de-stimulant:

Whereas the following relation is used for the

$$
Z_{i j}=\frac{\max \left(x_{i j}\right)-x_{i j}}{R\left(X_{j}\right)}
$$

In the case of a neutral variable it is first required to define the optimal range for values $\left\langle c_{1 j}, c_{2 j}\right\rangle$ as it affects standardisation:

$$
\begin{array}{lc}
\text { if } x_{i j}<c_{1 j} & Z_{i j}=\frac{x_{i j}-\min \left(x_{i j}\right)}{c_{1 j}-\min \left(x_{i j}\right)} \\
\begin{array}{l}
\text { if } c_{1 j} \leq x_{i j} \\
\leq c_{2 j}
\end{array} & Z_{i j}=1 \\
\text { if } x_{i j}>c_{2 j} & Z_{i j}=\frac{x_{i j}-\max \left(x_{i j}\right)}{c_{2 j}-\max \left(x_{i j}\right)}
\end{array}
$$

However, if there is one nominal value $c_{0 j}$ then we use the following relationships:

$$
\begin{array}{lrl}
\text { if } x_{i j}<c_{0 j} & Z_{i j}=\frac{x_{i j}-\min \left(x_{i j}\right)}{c_{0 j}-\min \left(x_{i j}\right)} \\
\text { if } x_{i j}=c_{0 j} & Z_{i j}=1 \\
\text { if } x_{i j}>c_{0 j} & Z_{i j}=\frac{x_{i j}-\max \left(x_{i j}\right)}{c_{0 j}-\max \left(x_{i j}\right)}
\end{array}
$$

In this case we are dealing with stimulants, which means that for calculations we will use the relation (5). For example, for the pendulum method and the criterion 'inland body of water' the calculations will be as follows:

$$
Z_{11}=\frac{x_{11}-x_{11}}{R\left(X_{1}\right)}=\frac{7-7}{2}=0
$$

Whereas in the case of the pendulum method and the 'poor visibility' criterion, the following equation applies:

$$
Z_{16}=\frac{x_{16}-x_{86}}{R\left(X_{6}\right)}=\frac{2-1}{8}=0,125
$$

When summing up the thus calculated $Z_{i j}$ values, a numerical evaluation of the decision variant is established for the pendulum method and the analysed criteria, which mean that in this case the results are as follows:

$$
\begin{aligned}
Q_{j}=\sum_{j=1}^{s}\left(Z_{i j} \cdot \varpi_{j}\right) & =0+0+0,033+0 \\
& +0,083+0,020+0,033 \\
& +0,071+0=0,245562
\end{aligned}
$$

Therefore, taking into account the analysed criteria, the assessment of the possibility of using the pendulum exploration method is as follows:

$$
Q_{1}=0,242262
$$

Unfortunately, this is information which does not yet tell us much. Calculations should be made for all decision variants, for each analysed search method. After performing calculations for each decision variant, the results of which are presented in the table below, with numeric values for each analysed variant, we can build a ranking on their basis and evaluate the variants. 
Results of calculations for dependency (4) for particular decision variants.

Method $\quad Q_{j}$

\begin{tabular}{ll}
\hline Pendulum & 0.242262 \\
\hline Field & 0.629762 \\
\hline Circular & 0.620437 \\
\hline Tack & 0.274008 \\
\hline Tow & 0.274008 \\
\hline $\begin{array}{l}\text { Sonar } \\
\text { survey }\end{array}$ & 0.516667 \\
\hline Magnetic & 0.683333 \\
\hline Television & 0.193651
\end{tabular}

When evaluating the variants, we divide them into best, average and worst, and for this purpose we use the $U$ constant calculated from the following relation:

$$
U=\frac{\max Q_{j}-\min Q_{j}}{i}
$$

In such a case, the criterion for assigning particular variants to a specific group is as follows:

$$
\begin{array}{ll}
\text { if } Q_{j} & \text { the best decision } \\
\in\left(\max Q_{j}-U ; \max Q_{j}\right) & \text { variant } \\
\text { if } Q_{j} & \text { the average } \\
\in\left(\max Q_{j}-2 U ; \max Q_{j}\right. & \text { decision variant } \\
-U\rangle & \\
\text { if } Q_{j} \in\left(\min Q_{j} ; \max Q_{j}\right. & \text { the worst decision } \\
-2 U\rangle & \text { variant }
\end{array}
$$

In the analysed case the value of $U$ equals:

$$
\begin{aligned}
U=\frac{\max Q_{j}-\min Q_{j}}{i} & =\frac{0,68333-0,193651}{8} \\
= & 0,06121
\end{aligned}
$$

This implies that the ranges determining the belonging of a variant to a specific group will be as follows:

$$
\begin{aligned}
& \text { if } Q_{j} \\
& \in(0.62212 \div 0.68333) \\
& \text { if } Q_{j} \\
& \in(0.560913 \\
& \div 0.62212\rangle \\
& \text { if } Q_{j} \\
& \in(0.193651 \\
& \div 0.560913\rangle \\
& \text { the best decision } \\
& \text { variant } \\
& \text { the average decision } \\
& \text { variant } \\
& \text { the worst decision } \\
& \text { variant }
\end{aligned}
$$

Now, from the point of view of the calculated numerical ranges (20), we are going to analyse the results presented in Table 8. The graphical representation of the results of the analysis is presented below.

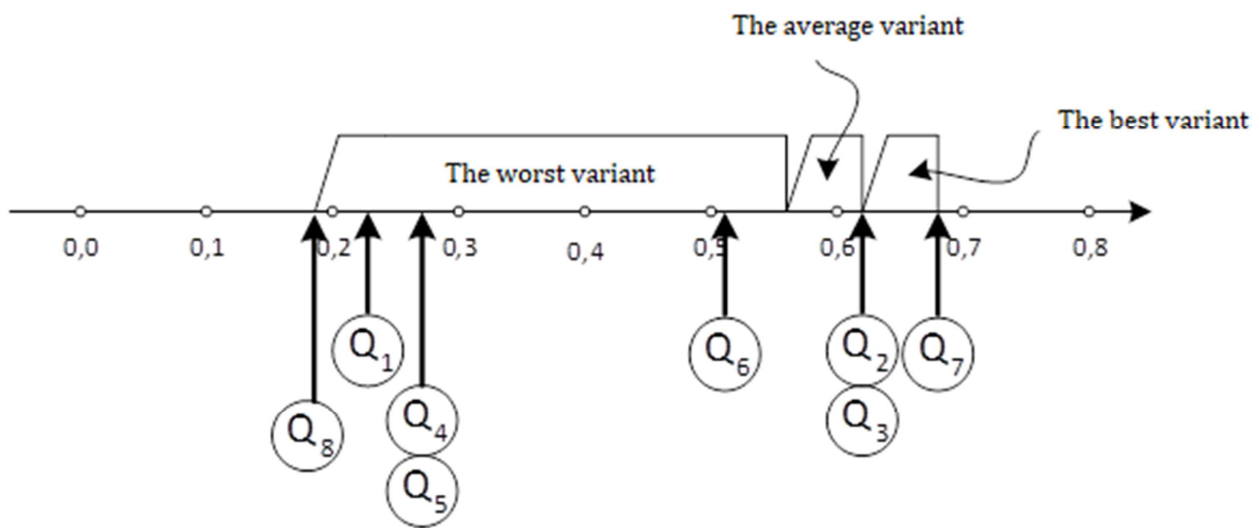

Fig. 1 Graphic representation of analysis results. 
The above figure shows that the variant marked with number 7 has been classified among the best variants with the score $Q_{7}=0.683333$, i.e. search method using magnetometer. On the border between the group of best and average variants there are variants marked with the numbers 2 and 3 with scores $Q_{2}=Q_{3}=0.620437$, i.e. field and circular search methods. In the group of average variants no other analysed method occurs. The group of the worst variants, on the other hand, included the other analysed search methods marked with numbers 1,4,5,6 and 8, i.e. pendulum (1), tack (4), tow (5), sonar survey (6) and television (8) methods.

\section{RESULT}

The calculations and analyses carried out demonstrate that in the analysed case the most effective procedure adopted for implementation will be a preliminary search of the body of water with the use of a magnetometer and selection of positions for a thorough search with the use of the field or circular search method.

\section{Conclusions}

This article presents an example showing the use of one of the decision optimisation methods to select an underwater exploration strategy. As can be seen from the analyses and calculations carried out, this method identifies the optimal variants of operation when searching for an object in a given body of water. As a result of the calculations, it has been suggested that two or three analysed strategies should be applied in order to increase the likelihood of their effectiveness. The results directly indicate the correctness of the procedure, which is proved by the fact that variant 8 (television method) was classified as the worst variant. As shown in Table 1, this method gives the best results when used on a limited area with good visibility without vegetation and on a hard bottom. Taking into account the characteristics of the body of water in the analysed example, these are conditions contradictory to those recommended for the application of this method.

The above indicates that a zero unitarisation method can be successfully applied during the preparation phase of underwater exploration to reduce the effort and resources required for its implementation. Its application, however, requires a competent team of underwater technology specialists who, as competent judges, will first perform an appropriate analysis of a given exploration area, define the criteria, and subsequently evaluate each of them.

\section{REFERENCES}

1. Olejnik A., Szymański R.: Methodology of selection of underwater search strategies implemented for the purpose of process development depending on the place and conditions of search; Polish Hyperbaric Research ISSN 1734-709; e-ISSN 2084-0535; Vol. 52 Issue 3 pp. $29-34$ DOI: $10.1515 / \mathrm{phr}-2015-0014$;

2. Lachowicz T.: Optimalisation of multi-criteria decisions with regard to safety; Studia Ekonomiczne. Zeszyty Naukowe Uniwersytetu w Katowicach ISSN 2083-8611; No. 235 (2015) pp. 144 - 158;

3. Połóński M.: Multi-criteria analysis - an introduction

http://mieczyslaw polonski.users.sggw.pl/Analiza\%20wielokryter\%20wstep1.pdf - accessed on 08.2018;

4. Kukuła K.: Zero unitarisation method against the selected methods of normalisation of diagnostic features; Acta Scientifica Academiae Ostroviensis nr 4 (1999) pp. $5-31$;

5. Collective work under the supervision of A.Olejnik Technical-economic study of underwater works; unpublished material, research work commissioned by the District Prosecutor's Office of Praga District, Warsaw;

6. Kukuła K., Jędrzejczyk Zb., Skrzypek J.: Operational research in examples and exercises; Wyd. PWN 2016; ISBN 978-83-01-18468-1.

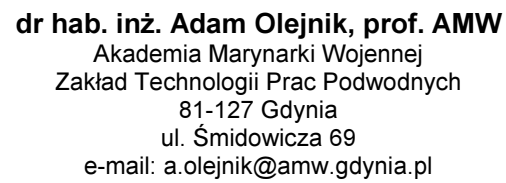

